\title{
Islamic and Social Entrepreneurships for Social Justice: A Policy and Structural Framework for Social Enterprise Economics
}

\author{
Rafiqul Islam Molla \\ Academic Adviser \\ International Islamic University Chittagong, Bangladesh \\ Email: rimolla@gmail.com \\ Md. Mahmudul Alam \\ Senior Lecturer \\ School of Economics, Finance \& Banking (SEFB) \\ College of Business (COB) \\ Universiti Utara Malaysia (UUM), Malaysia \\ Email: rony000@gmail.com
}

Abul Bashar Bhuiyan

Senior Lecturer

Universiti Malaysia Perlis, Malaysia

A. S .A. Ferdous Alam

Institute for Environment and Development (LESTARI)

National University of Malaysia (UKM), Malaysia

\section{Citation Reference:}

Molla, R.I., Alam, M.M., Bhuiyan, A.B., and Alam, A.S.A.F. 2015. Islamic and Social Entrepreneurships for Social Justice: A Policy and Structural Framework for Social Enterprise Economics. Al-ijtihad: Journal of Islamization of Knowledge and Contemporary Issues. Vol. 13 (1), pp. 1-27.

This is a pre-publication copy.

The published article is copyrighted by the publisher of the journal. 


\title{
Islamic and Social Entrepreneurships for Social Justice: A Policy and Structural Framework for Social Enterprise Economics**
}

\begin{abstract}
Entrepreneurship is indispensable for progress of human civilization and effectively exploring and exploiting existing and potential resources for wellbeing of humanity. Modern economics operates basically through two major modes of entrepreneurships: the market/private sector economics relying on commercial entrepreneurships (self-interestcentric) and the state/public sector economics relying on state entrepreneurships (publicwellbeing-centric). However, both have, individually and jointly, failed to ensure economics' fundamental goal of wellbeing for human societies. In response, a community wellbeingcentric social enterprise economics (third sector), which features cooperatives and not-forprofit social enterprises in the name of foundations, trusts/awqāf, social businesses, and similar undertakings, has emerged as a make-up strategy to meet the minimum unmet requirements for social wellbeing. However, there is a strongly felt belief that this community wellbeing-centric social enterprise economics needs to be broadened and mainstreamed in order to include entirely charitable institutions, predominantly not-for-profit operations, and predominantly for-profit businesses but blended with provision of social welfare programs like corporate social responsibility, etc., for its emancipation as a major economic system to be able to play a leading role for ensuring desirable economic growth and development. Islamic entrepreneurship, which is basically a community-centric mode of business initiative, is closely related to social entrepreneurship. It is an antidote to the problem of intolerable economic and social dualism and a natural strategy against all forms of capitalist exploitation to control world resources, like, in the past, through European colonialism, and now, through American-led state terrorism. It is the natural guard against economic inequity, wealth concentration, and social divides. Based on its potential and using examples from Bangladesh and Malaysia, we argue that the Islamic style social entrepreneurship, which is operationally a profession for a mission, is intellectually and operationally superior and more efficient for effectively widening and mainstreaming community-centric social enterprise economics to ensure development with equity and social justice. The paper aims to put forward social enterprise economics (third sector) for dialogue and research in the context of effective functioning of modern economies ensuring community wellbeing.
\end{abstract}

Key words: entrepreneurship, community-centric, American-led terrorism, not for-profit business, economic \& social dualism, capitalist exploitation, social justice, public sector, private sector.

\section{Introduction}

\footnotetext{
*The earlier versions of the contents of this paper were published in i) Molla, R.I., Alam, M.M. 2012. A Third Sector-Led Economic Model: Scopes for Islamic Entrepreneurship, American Journal of Islamic Social Sciences, Vol. 30(1), pp. 73-91, ii) Molla, R.I., Alam, M.M. 2011. Mainstreaming Third-Sector Economics by Adopting Islamic Principles of Entrepreneurship, Dialogue \& Alliance, Vol. 25 (2), pp. 33-46, and iii) were presented as a Keynote Paper at the Australian Academy of Business and Social Science Conference 2014, Kuala Lumpur, Malaysia, 25-26 August 2014.
} 
Entrepreneurship is more than just starting a business or two; it is about having the proper attitude and the drive to succeed. Entrepreneurs are the economy's initiators and drivers. They are usually persons (or enterprises) who pioneer changes. They are essential human resource in any economy. They are very scarce. Islam considers the role of entrepreneurs as fardekifia (obligatory upon the society, i.e. it has to be performed at least by some members in the society). For the fact that they are essential and scarce resource of the society, they are considered as social assets meant more for social benefits. They are very few, particularly in the developing countries. Entrepreneurial abilities and qualities, which are very scarce and valuable, are needed to make further improvement upon which already exists and to create new goods and services.

Various western scholars have summarized the common personal qualities of successful entrepreneurs for market economics as follows: the inner drive to succeed and being very ambitious; having a strong belief in themselves and an assertive personality; creative and searching for new ideas and innovations; open to change and therefore dynamic in nature; competitive by nature; highly motivated and energetic with an abundance of selfmotivation; able to accept constructive criticism and rejection; and having a positive attitude. But the most essential ones, at least from the perspective of community wellbeing, like motives to serve the society and social goals and values, and commitment to ethics and religious values, are not present in this list. These are, in fact, the items of personal qualities that differentiate from the Islamic and social entrepreneurships (of the social enterprise economics) from the commercial entrepreneurships (of market economics).

Disciplinary development of modern economics is pursued through ideologically and operationally basically two dominant modes of entrepreneurships : the market/private sector economics relying on commercial entrepreneurships (self-interest-centric) and the state/public sector economics relying on state entrepreneurships (public wellbeing-centric) for achieving the economics' fundamental goal of 'societal-wellbeing'. But because of the limitations and failures of both the modes, the social and Islamic entrepreneurships (community wellbeing-centric) in the form of third sector economics are now emerging.

The Commercial Entrepreneurship (market economics) is founded on the fundamental assumption that self-interest is the sole motive of human behaviour and actions. It relies on methodological individualism and profit maximization on the assumption that individual benefits, when added together, will maximize society's benefits. It has two main features: (1) the individual's benefit is placed at the center, and (2) it is based on free market competition, meaning that the "strongest takes it all" following the Darwinist social philosophy of "survival of the fittest"(Molla et al. 2011).

Having been armed with superior mathematical tools of marginal analyses economics became tempted to build it as a science and the darling queen of social science. Unfortunately however, it risked losing its soul i.e. the goal of community wellbeing.

State Entrepreneurship (public sector economics), on the other hand, puts society methodologically at the centre and relies on the philosophy that society's benefit is the summation of all individual benefits. Therefore, when society's benefit is addressed, it takes care of individual's benefit.

Market-State Entrepreneurship (Mixed sector economics): By the beginning of the twentieth century, people realized that the market alone could not be trusted to ensure 
community wellbeing. This led to the idea of the state's necessary involvement and participation side by side with the market i.e. a market-state mixed economy where the market would produce and supply mainly the private goods and the state would produce and supply primarily the public and collective goods. This model was initially enthusiastically accepted by academicians, professionals, and policy makers. However, serious shortcomings of this economic model surfaced when the income inequalities within and among nations continued to increase.

Social Entrepreneurship (Third sector economics): Non-conventional economic approaches together called Social Enterprise Economics comprising cooperatives and social entrepreneurships, charities - foundations, trusts, waqfs - and other non-profit institutions have been introduced and promoted as more capable of ensuring humanity's wellbeing (Stiglitz, 2009). The third sector economics was introduced primarily as a make-up for the deficiencies of the private and public sector economics. It was meant for operating in the peripheral sectors of the economy to meet the minimum unmet requirements for social wellbeing. However, it has been found to be potentially highly viable and effective economic system for economic growth and development with social justice. Therefore, there is a need for it to be broadened and mainstreamed.

The Objectives of this article is to position the social enterprise economics (third sector economics) as a better and more effective economic system for development with social justice required for a better world, and provoke the intellectual minds, economic and social planners and managers for policy dialogue and research for its theoretical, structural, and managerial development required for its mainstreaming and emancipation as a major economic system to play leading role standing side by side with the other major systems.

\section{Shortcomings and Failures of the Mainstream/Dominant Entrepreneurships}

\section{Conceptual and Functional Irrelevance}

Adam Smith in The Theory of Moral Sentiments observes that human beings are naturally sympathetic to fellow beings. They are endowed with two instincts: self-interest and sympathy for others. Therefore, the entrepreneur's natural behaviour is expected to be for earning a profit, but within the framework of social justice. To ignore the multifaceted nature of human motives for action and rely on self-interest as the sole motive is to distort the truth. Maximizing or seeking excessive profit (profiteering) without due regard for social wellbeing is not a legitimate right. A science founded on a distorted fundamental assumption cannot be sound, reflective and reliable. Its failure is a natural outcome and obvious. Again there is the Paradox of the dictum of 'invisible hand' of market competition. In that, competition meant for market perfection, instead produces market imperfection for exploitation. The Pervasive drive and competition for capital accumulation and search for new technology and markets produced British Economic Imperialism and American state Terrorism for control and exploitation of world's industrial raw materials (especially oil, natural gas, exotic resources) and markets for their industrial and war materials (Chomsky, 2001; The Berlin Tagesspiegel Daily, 2002; Chronology of American State Terrorism, 2014).

With the introduction of marginal analyses and unnecessary love for gaining excessive mathematical and technical proficiency to become a science - science of prediction, it had to disentangle itself from social and moral determinants and become a soulless and heartless dismal science. It became largely irrelevant for study of economic 
problems for human society. During 1960s economic literature became loaded with so much of mathematical expositions that it had to face the criticism like:

a) 'Is economics a study of mathematics or phenomena of economic behaviour of human being ?' and b) 'Is mathematics the master or tool of economics?'.

And yet we are conditioned and brainwashed to believe in the theories they formulated and promoted as reflective of the reality of human motivations, behaviours, and actions. We are taught and made accustomed \& habituated to think and behave according to the theories formulated based on distorted assumption and vision about the true nature of motives for human action and behaviour.

\section{Failures}

In one hand, the principle of profit maximization without regard for social justice led private sector enterprises to exploit others and concentrate wealth in the hands of the small group of capital-owning private sector business enterprises. On the other hand, the state's inherent inability to handle economic/business operations resulted in gross inefficiency and economic losses in the public sector. The significantly increasing income inequalities eventually became so obvious and embarrassing that the 2001 report put out by the UN High-Level Panel on Financing for Development lamented by saying that:

Sadly, increasing polarization between the haves and have-nots has become a feature of our world. Reversing this shameful trend is the preeminent moral and humanitarian challenge of our age (United Nations, 2001).

The World Development Indicator 2007 reported that in $200584 \%$ of world's population received only $46 \%$ of the world's income (Todaro, 2009). The Gini coefficients of the world's income and wealth distributions are 0.619-0.68 and 0.892 respectively, which signify an extremely high inequality level of global income and wealth distribution (Hillebrand, 2009; Sutcliffe, 2007; Davies, 2008). The richest 1\% of adults own $40 \%$ of the world's wealth, and 2\% own more than half of the world's household wealth. Even the wealth inequality within nations is too high: the wealth Gini of Japan is 0.55 , and the wealth Gini of the United States is about 0.8. Moreover, this model has failed to eliminate the most acute forms of poverty in many societies and countries, as because it has failed to capture the essence of what it is to be humane. The excessive emphasis placed on self-interested and competitive behaviour has weakened feelings of social unity, and thus the social bonds among people. I has diminished relations built on trust and cooperative behaviour. Such negative developments heighten people's sense of vulnerability and fears for the future (Borzaga, 2009). The increased economic growth thus has not been matched by increased wellbeing and happiness. Therefore, both private and public sector economics have been found seriously inadequate for the task of ensuring wellbeing of societies and nations. Various attempts made to remedy the shortcomings of this model, such as reducing the size of the public sector via transferring many public sector enterprises to the private sector, known as privatization, did not yield the expected results. This indicates how difficult it is to obtain socially responsible behaviour from agents concerned only with maximizing their selfinterest.

\section{Causes for Failures}


Their following conceptual and operational shortcomings can be ascribed as the fundamental causes of their failures.

a) Any social system or culture to be operationally successful, effective, and sustainable, must have three fundamental components : legitimacy, order, and welfare/wellbeing (LOW). That is, it must have the acceptability and respectability, and commitment. It must be organized and guided by principles for orderliness. It must be for wellbeing of society.

Market economics is well organized and ordered. But it is predominantly for serving self-interest. Its lacks legitimacy in the sense that it lacks commitment to value of societal wellbeing ingrained in human nature, and thus it lacks moral acceptability and legitimacy. It is founded on a distorted assumption of self-interest as the fundamental human motivation for behaviour and action. It ignores the multifaceted nature of human motives and suffers from lack of concern for societal wellbeing.

b) Over the years it gained greatly in mathematical and technical proficiency to qualify as a science to earn the name as 'darling queen' of social sciences, and finally to secure a place in the list of disciplines qualified for the award of the most prestigious Nobel Prize. In attaining this exalted position as a science - science of prediction economics had to disentangle itself from social and moral determinants. It was thus reduced to a discipline with very narrow scope.

c) For its entirely materialistic view and unnecessary love for excessive objectivity and quantitative nicety it became a heartless and soulless dismal science incapable of catching and explaining the spiritual aspects of human wellbeing \& satisfaction, behaviour \& actions. It was subjected to a great deal of criticism on the ground that it became increasingly irrelevant for understanding and solving major economic problems of the real world.

d) Moreover, there is a paradox in Smith's maxim of 'invisible hand' of market competition : the competition meant for producing perfectly competitive market, instead produces and ensures imperfect market for exploitation.

\section{Emphatic Role of Islamic Entrepreneurships for Economic Growth \& Development}

Islam regards entrepreneurship as essential and indispensable for progress of human civilization and effectively exploring and exploiting existing and potential resources to benefit mankind. In Islam, engaging in business activities is like performing a duty that is obligatory upon the community (fard-al-kifāyah) as opposed to the individual. This obligatory duty must be performed by at least one or some on behalf of the entire community. To have no entrepreneur in a community is regarded as sinful for the entire community. This is how seriously Islam perceives and encourages entrepreneurship, and why it has made this activity a societal, as opposed to a personal, obligation. Those who seek to fulfil it must seek to pioneer continual change through innovations in the economic environment, first and foremost, for society's benefit. Earning profits for themselves is incidental. Islam endorses entrepreneurship, regardless of whether it is driven by opportunity or necessity, as long as it is based upon a solid moral and ethical ground and conforms to Islam's code of conduct. Entrepreneurship in western societies is mainly driven by the prospect of material rewards. Islam has nothing against this goal; however, those involved in this sphere must realize that every business undertaking is a form of religious duty intended first to meet Allah's wish, second, to satisfy society's needs, and third, to generate a reasonable income for the owners. Islamic entrepreneurship is not against seeking a reasonable profit, but it does put ethical consideration and community interest first. Given that Islam aspires to create high quality 
entrepreneurs and productive Islamic entrepreneurship, Muslim entrepreneurs are permitted and encouraged to be involved only in morally accepted and socially desirable productive business activities. Therefore, all activities associated with alcohol, drugs, usury, prostitution, any illegal, unethical \& immoral activities, gambling, and highly speculative business behaviours are strictly prohibited, despite the possibility of their economic viability.

Islam views entrepreneurship from a larger perspective, and thus entrepreneurs assume an altruistic role that goes beyond satisfying their immediate needs and personal interests. Given this, the pursuit of self-interest and self-centered wealth creation are not the primary motives. Altruistic motives override personal considerations, due to the conviction that one's self-interest will be realized as a natural outcome while pursuing society's common welfare. The entrepreneurs' personal motives for starting their businesses are considered important factors that explain the status and direction of entrepreneurship in a country. Their ability to orchestrate and lead the economic transformation, as well as to carry out the needed fundamental cultural and socio-economic changes, depends greatly upon the entrepreneurial motives of the new business founders. Besides being holistic in approach, Islamic entrepreneurship insists that entrepreneurs must first be religious people and be motivated by success both in this world and the next. Islam views entrepreneurial success as not confined to merely the bottom-line principle of earning profit and material wealth. In fact, entrepreneurship is considered an integral part of Islam, which encourages its members to engage in business as part of doing good deeds. Muslim entrepreneurs, just like other Muslims, are considered Allah's agent (vicegerent) and thus are guided by the ethics and values prescribed by the Qur'an and the prophetic Sunnah.

\section{Emergence of the Social Enterprise Economics (Third Sector)}

The basic goals of economics are allocative efficiency, distributive efficiency, social justice, and balanced development for all. Distributive efficiency, a value-driven function, includes the universally desired socioeconomic goals of need fulfilment, full employment, an optimum rate of economic growth, an equitable distribution of income and wealth, economic stability, and ecological balance. All of these are generally considered indispensable for actualizing societal wellbeing goal of economics. But when driven by profit maximization, mainstream market economics is highly deficient and unable to meet these normative goals. Due to its secularist worldview, characterized by a materialist and social Darwinist outlook, conventional economics fails to specify the necessity of individual behaviour to serve the public interest. ${ }^{\dagger}$ What is required now, therefore, is a new paradigm that can achieve this

\footnotetext{
For conventional economics, ethics and morality is not based on humanity. For example, economic agents measure and judge what is right/wrong and good/bad according to "more is better" and "survival of the fittest." Thus producers are motivated to provide those goods and services that earn them the highest profit, as opposed to meeting society's needs, regardless of their effect. In such a situation, as Samuelson noted, producers may not be motivated to produce milk essential for babies of low income families if they cannot pay a high price for it (Samuelson, 1967). They would rather produce dog and cat food if high income families will pay higher prices for it. Unfortunately, for the ethics of market economics such negative reality is a matter of indifference, because ethics of market economics provide no moral guidance to the system's economic agents(European Research Institute on Cooperative and Social Enterprises, 2014; UNDP, 2008).
} 
purpose and goal in the most effective manner possible (Blaug, 1980; Balogh, 1982; Chapra, 1996). A new balance must be found among markets, governments, and other institutions (e.g., not-for-profit and cooperatives) in order to build a plural economic system with several pillars (Stiglitz, 2009). Scholars also see cooperatives and social enterprises as better able to coordinate collective action, promote collaboration, enhance trust, and increase freedoms.

This approach seeks to achieve this by mobilizing and demanding that entrepreneurs direct their work toward benefiting society by making social benefit the prime mover of their entrepreneurialism. Initially, it emerged as a make-up and defensive strategy of the marketstate model to meet the minimum unmet requirements for social wellbeing. It is typically conceived of as an economic model comprising the not-for-profit, non-government, and other organizational bodies that can provide personal and collective services more efficiently than either for-profit or public organizations. Cooperatives and social enterprises are the two main movements of third sector economics. A cooperative can be defined as a voluntary organization (e.g., a farm or a firm) that is owned and managed jointly by its members for a common goal and that shares benefits among themselves; and serving the community is only incidental (International Co-operative Alliance, 2014). Social entrepreneurship, which includes social business, is a "social mission driven" business organization. Operationally, it is 'a profession for a mission'. Filipe Santos (2009) defines it as an activity that focuses primarily on value creation rather than value appropriation. These are business-like operations, but their main concern is not business; rather it is to satisfy a social need while being economically sustainable. It is a complementary economic approach that is based on predominantly value creation. Therefore it has to have its own self-regulations and operating rules. It may be described as any for-profit or non-profit organization that applies capitalistic strategies to achieve philanthropic goals without any ulterior motive. It can be, therefore, described as "doing charity by doing trade," rather than "doing charity while doing trade." For social business, according to Muhammad Yunus (2007), the key differentiating element is that the investors can receive back at best their original investment, for there is no additional dividend or capital return. But a social enterprise is allowed earning reasonable/normal profit for sustainability and normal growth. Therefore, in terms of concept and scheme social enterprise includes social business, meaning that all social businesses are necessarily social enterprises, but not the other way. Social business is necessarily a nonprofit enterprise in which the investor is not entitled to get any dividend, but at best can get back their original investment gradually from out of the profit/surplus earned by the enterprise. In that sense, the capital invested by the entrepreneur will be in the nature of Islamic Kard-e-Hasan to the enterprise.

Social enterprises, can be classified in a variety of ways as a) in terms of, Islamic, Islamic style, and non Islamic, b) in terms of, for-profit, not for-profit., c) in terms of, government organizations (GO), non-government organizations (NGO), and d) in terms of, social businesses, non-social businesses, etc.

Some recent theoretical developments have helped strengthening the academic and analytical arguments for the social enterprise economics (European Research Institute on Cooperative and Social Enterprises, 2014). New theories have shifted away the emphasis from viewing the firm as an entity centred on profit maximization to one of working as a coordinator with the goal of solving society's problems via the production of goods or services. This has broadened the firm's role to include both production of public and 
collective-interest goods. Similarly new theories on human behaviour and action suggest that every human action and, in particular, every economic action is not governed exclusively by self-interest. The Behaviourist School maintains that human actions spring from a mix of motivations (e.g., intrinsic, extrinsic, self, others) and are influenced by a general ethical factor of inclination to help each other and uphold justice and equity. These theoretical developments clearly point to the truth that human beings are fundamentally ethical social beings and, secondarily, economic beings. In fact, this is the message of Islam and all other revealed religions. These two theoretical developments have helped explain why the objective of an enterprise is, or can be, to solve a collective problem. These provide the rationale for social enterprise economics. Another justification can be seen from the fact that even the market economics proposes perfect market as the best condition for maximizing society's wellbeing, in which entrepreneurs earn only normal profit as part of the economic costs. The 'invisible hand' of competition is expected to produce perfectly competitive market in which excess profit is withered, and only normal profit is earned by the entrepreneurs making production to take place at the lowest cost for maximizing society's wellbeing. Therefore, the market economics i.e. the commercial entrepreneurship as well, focuses on the same motivation of earning only normal profit (satisficing on personal benefit) and maximising community benefits as the best and desirable condition. But unfortunately by its contemporary nature the free market system, because of its profit maximization maxim, cannot produce perfect competition. Attempting to promote market competition for creating perfectly competitive market, paradoxically, it is produces and promotes imperfect market. Therefore, in market economics a wrong and unnecessary methodological emphasis has been put on profit maximization as a maxim. In fact the deeply ingrained general motivations of entrepreneurships is the community wellbeing and earning normal $\&$ fair profits for sustainability and growth. Since market economics is founded on the distorted fundamental assumption that self-interest is the sole motive of human behaviour and actions, it cannot be sustainable. Human nature cannot be conditioned to follow any artificial assumptions formulated based on convenience and emotions.

Under the circumstances the social enterprise economics (third sector) led by social and Islamic entrepreneurships is now seen as the most viable and needed economic model that can ensure realization of economics' fundamental goal: humanity's wellbeing at the national and global levels.

\section{Its Affinity with Islamic Economics}

Social enterprise economics and Islamic economics seek to achieve similar objectives: humanity's collective benefit, balanced and just economic development, the equitable distribution of income and wealth, the narrowing of income gaps, closer understanding and trust among nations and societies, and an increased quality and standard of living for everyone. In that, economic development, as a means for community's wellbeing, can be considered as realized only after everyone's needs have been met, the generated income and wealth have been distributed equitably, and full employment and environmental protection have become realities.

Islam's commitment to cooperation and justice makes the wellbeing ( falāh) of all human beings its principal goal. Given that this wellbeing is achievable by the balanced realization of humanity's material and spiritual needs (Chapra, 1993), the mere maximization of total output cannot be the goal of a society. It needs, in addition, simultaneous efforts to 
ensure the persons' spiritual health at the inner core of human consciousness and interactions. In fact Islamic economics and entrepreneurship are geared towards that direction.

Islamic economics is founded on the principle of goal realization rather than profit maximization, as ethics dominate economics. This "ethical factor" fundamentally sets the Islamic system apart from all other economic systems (Naqvi, 1981), because ethics epitomize a society's common values and determines its members' preference structures. The separation of economics from ethics is not practicable, because ethics set the tone for economics and thus the rules of economic behaviour based upon Islam's ethical norms. Therefore it is a value-driven system fundamentally to meet the ethically determined and demanded normative goals for the society's wellbeing: a just and balanced social system - "a social environment that brings a sense of community and fellowship in human relationships" - that demands for the official recognition of justice, human dignity, and compatibility among humanity, technology, and the natural environment. Such a social environment requires far more than economic growth and prosperity, and more than the so-called efficient allocation of resources. Therefore, this system supports the view of economic development, described by Myrdal, as an upward movement of the entire social system, or simply growth plus change in the redistribution of income in favour of the lower income groups so that economic dualism is avoided. In Islam economic development is viewed as only one element of social wellbeing. It is important, but only as a contributor to the spiritual, material, and social uplift of human beings. Thus entrepreneurship is geared toward ensuring an expansion of production that benefits and improves everyone's quality of life, thereby allowing them to enjoy conveniences and a moderate amount of luxuries (but avoiding extravagance) (Molla et al. 1988). To the extent the entrepreneurs' focus and driving force is community (as opposed to individual) benefit, social enterprise economics and Islamic economics have a great deal in common.

\section{Its Peripheral Image}

Unfortunately, at the beginning, social enterprise economics was conceptually, structurally, and functionally meant and designed as special programs to deal with primarily the economy's peripheral areas: poverty alleviation, rural development, and agricultural development. This gave the two other models a free hand to operate in all of the economy's dominant and growth-generating sectors. Moreover, there was a widespread belief that social enterprise economics were best suited to providing personal- and community-care services. This reflects the tendency of even donors and international agencies to promote cooperatives and social enterprises only as tools to reduce poverty and generate employment (UNDP, 2008). As a result, social enterprise economics remained outside the mainstream economy and did not gain the necessary recognition and respectability. However several large and successful social enterprises (SEs) have appeared in Asia, such as the Grameen Bank and Bangladesh Rural Advancement Committee (BRAC), in Bangladesh, and the Population and Community Development Association (PDA), in Thailand. All of them received extensive government and donor supports. The other SEs, which are small or mid-sized, are nonetheless having some successes at realizing the socioeconomic goals in both the for-profit and not-forprofit sectors (Shahnaz and Tan, 2009). But despite its invaluable contributions to bridging social divides and achieving the community's wellbeing, this sector is not receiving the expected attention and recognition for its development and expansion to be able to play a more effective role side by side with the dominant first and second sector economics for achieving a balanced and sustainable national economic development. The social enterprise economics is, rather, treated as a peripheral activity and sidelined in the management of the 
national economic sphere. Therefore, if it is to emancipate to play its envisaged and expected role as a leading economic system, it must be broadened and mainstreamed.

\section{Scopes and Potentials for its Emancipation as Mainstream Economics and Call for Restructuring}

With its community-centric conceptual base and social justice-driven motivation, the social enterprise economics (third sector) stands as the superior economic model for goal realization. In addition to having the best potential to manage the economy most effectively with a human face and heart, it is also a very effective and desirable strategy to attain sustainable growth and equitable development for everyone. Unfortunately, as noted earlier, it has remained, both conceptually and operationally, largely confined at the economy's peripheral areas to serve primarily as filler of gaps. Typically, it covers the activities of nongovernment and not-for-profit bodies comprising cooperatives and not-for-profit social enterprises. This not-for-profit narrow base has seriously limited its growth and expansion, as well as its entry into the growth-yielding and more challenging industrial sectors of the mainstream economy.

Profit seeking and profit making are the legitimate rights of entrepreneurs as because, no enterprise can survive and remain in business if it cannot and does not generate a reasonable and desirable amount of profit. This is why the normal profit, without which the business would fail, is calculated as a part of economic cost. Therefore, social enterprise economics should not remain confined to not-for-profit activities; rather, its spirit and essence demand widening of its sphere and domain of operations through both not-for-profit and forprofit modes of operation. Many people expected that it should become another dominant model - one that works not only for poverty alleviation, but also for enhancing economic growth in order to bridge the economic and social divides. Accordingly, in recent decades attentions were drawn to the need for widening the scope of its goals and objectives, not to mention expanding its spheres of operations. Accordingly, there is need for expansion of its conceptual base, domain of operations, and types of enterprises and objectives. It should expand beyond cooperatives and non-profit social businesses to for-profit businesses to inject its provisions for social justice into the economic mainstream. Neither a not-for-profit nor a profit maximizing objective alone can serve as the natural theme of general/mainstream economic activities. Rather, such behaviours could be special cases for special circumstances. Perhaps a mixture of the two could somehow serve as the rules of behaviour for business entrepreneurs. Since people are endowed with two instincts: self-interest and sympathy for others, the entrepreneur's natural behaviour is expected to be for earning a profit, but within the framework of social justice. This, therefore, calls for necessary policy and institutional restructuring of the social enterprise economics for its needed broadening and mainstreaming.

\section{The Scopes and Nature of the Required Restructuring}

The restructuring of social enterprise economics should include the following additional types of enterprises in its list: (1) profit-driven businesses that contain some planned social benefit-driven operations, (2) public-private partnership (PPP) enterprises that feature social benefit as a control factor, (3) all Islamic business enterprises with ethics and social benefit as control factors, and (4) cooperatives that benefit their members but also have some planned operations devoted to community benefits. Accordingly, it should be restructured to include both not-for-profit enterprises and for- profit "businesses blended with social justice" so that 
it may ultimately become a large and dominant economic mode - one that is comparable with the market-based first sector as regards its share and control of the economy. With this expansion and restructuring, the third sector will be strong enough to have a significant impact on the behaviour and performances of the first sector. It will influence the first sector to moderate and blend its profit-maximizing behaviour with equity and social justice.

This restructuring will require:

1) A regulatory provision of registration for enterprises as social enterprise economics (third sector economics) specifying the plan of action they have devised to meet their commitment and accountability to community wellbeing and social justice.

2) Since profit maximization is not their basic or only reward, there should be regulatory provisions for an accreditation institution for assessing and rewarding them as a category by

a) socially respected trademarks (like for social enterprise S-E, social business S- B, cooperatives Coop, Islamic business enterprises I-B),

b) award of social titles as recognition to the successful enterprises and entrepreneurs, special financial and other supports from the government and other national and international organizations, in the event of a temporary financial crisis or genuine business failure, and

c) punishment through withdrawal of the awarded trademarks, social and economic privileges, in case of wilful negligence to their stated commitments, etc..

This new regulation for registration may conveniently accommodate the earlier regulations for NGOs, cooperatives, foundations, and similar organizations. Formation of the accreditation body is needed for monitoring, assessing, rewarding, and punishing the enterprises. Accordingly there should be gradation of trademark labels, awards and rewards based on the level of their declared commitments to social benefits and performances.

3. Similarly and more importantly, there should be provisions for

a) Institute for research, training and development on social enterprise economics,

b) management institute for research, training and managerial development of the social enterprise economics i.e. third sector economics,

c) Institute for training, studies, and research for entrepreneurship development,

d) Professional bodies for social and Islamic entrepreneurships, and

e) Particularly, regulatory support for revising and rewriting text books on economics business management, and sociology at all levels of studies to reflect the 'whole truth' about the human motives of economic behaviour and actions.

\section{Emphatic Scope of Islamic Entrepreneurship for Mainstreaming Social Enterprise Economics}


Right kind of entrepreneurship is required to guide and lead the economy toward development with social justice. Entrepreneurs in the market-led economy are motivated and driven by profit maximization. Community wellbeing, only now-a-days, through such provisions like corporate social responsibility (CSR) is only a residual consideration. More so, CSR is used mostly as a public relations instrument and a marketing strategy, with the motive of gaining market control for maximizing corporate profits (Corporate Watch Report, 2006). Corporations remain engaged in serving the need fulfilments of the haves while ignoring those of the have-nots. This kind of entrepreneurship and profit maximizing market economics harm society and have brought about all sorts of exploitation and oppression.

Islam calls upon people to resist all sorts of oppression and exploitation and work constantly for social betterment and development. Entrepreneurs in the Islamic mould are guided by Islamic ethics in their search for the best way to serve humanity. For them, the motivating factors are human wellbeing and Allah's pleasure. The unique ethical and motivational structure of Islamic entrepreneurship gives first priority to community considerations, and only then to individual benefits. It locates the community as the primary stakeholder of the output of any entrepreneurial action. It possesses all the 3 key qualities legitimacy, order, and welfare (LOW) - for success of any social system. It is faith-based and enjoys the legitimacy. It is guided by religious and moral codes and regulations and enjoys orderliness. It is predominantly for societal welfare. Islamic entrepreneurship, therefore, fits very well for social enterprise economics model with highest potential for success. Applying the principles of Islamic entrepreneurship, it can grow, expand, and attract large numbers of enterprises that are currently operating in the mainstream and growth sectors of the economy.

However, many entrepreneurs may not be so committed to Islamic convictions and spirituality. This is particularly true among non-Muslims, who obviously cannot be expected to conform fully to all the aspects of Islamic norms discussed above. Under these circumstances, any business that falls short of fully conforming to these norms but does conform reasonably well to all of its material aspects and community-centric spirit, may be called an 'Islamic-style' social enterprises. In this, output maximization, profit maximization, employee benefits, etc. issues are subject to community wellbeing considerations. Profits for the equity holders and benefits for employees are seen as residual matters.

\section{Examples of Community-centric Activities of Islamic Style Social Enterprises from Bangladesh and Malaysia}

\section{Islami Bank Bangladesh Limited}

One of the Islami Bank Bangladesh Limited's distinguishing features is that its overall activities are directed toward the society's overall welfare (Islami Bank Foundation, 2014). Its firm commitment to uplift and emancipate the country's poor people has resulted in the creation of a separate fund, the Islamic Bank Foundation, to carry out this social responsibility through

i. Income-generating self-employment programs (e.g., rickshaws, sewing, poultry keeping, rural health work, milch cow/goat rearing, and small trade) to provide access to the required finance and other inputs necessary.

ii. Education programs to improve the country's educational scenario by supporting Forquania Maktab, scholarships/grants to poor and meritorious students, and financial support to educational institutions. 
iii. Health and Medicare programs to extend health, medicare, and sanitation facilities to the urban and rural areas (e.g., establishing medical centers, supporting charitable dispensaries, lump-sum help for medical treatment, tube well installation, and sanitary latrine construction).

iv. Humanitarian help, relief, and rehabilitation programs for the poor and needy.

v. Dawah programs, such as working with prisoners to reform their morals.

vi. Monoram (beautiful) crafts and fashion programs that will allow distressed women find sales outlets for home-made garments, handicrafts, and other items. The other objective is to develop clothing that conforms to Islamic norms and that compare well with contemporary fashions.

vii. Service centers to be constructed in coastal areas, river deltas, and off-shore islands that can be used for social development as well as to provide shelters during natural disasters. Two such service centers have already been established in Noakhali and Manikgonj.

viii. Establishing international schools and colleges that will transform local youths into human capital with relevant technical skills. So far, it has established two technical institutes in Dhaka and one in Bogra that offer training in computer, secretarial science, driving, electrical, refrigeration and air conditioning, radio and television, and tailoring and garments.

\section{Johor Corporation (JCorp)}

The Malaysian state of Johor's government's investment agency, Johor Corporation (JCorp), is an example of successful Islamic entrepreneurship (Musa, 2010). By creating a corporate waqf, WAN Corp, it has successfully initiated a new way of doing business under the banner of "Business Jihad," an alternative to the purely shareholder-centric business-driven economic model. Its mission and slogan, "Building wealth for all with Islamic entrepreneurship," is based on the waqf. According to Islamic law, a waqf is a permanent endowment or trust, customarily of real estate, in which the proceeds are spent for purposes designated by the benefactor: to fund such charitable institutions as schools, orphanages, hospitals, and mosques. This newly created corporate waqf, a legally recognized communityowned corporation that continues in perpetuity, produces useful goods and services for society. Profits are reinvested or fund community interests in charitable or social causes to bridge the social divides. It is more or less like a "social business." Proponents claim that this approach largely adheres to the nature and character of Islamic entrepreneurship, for its ultimate goals are community and social justice. This staunchly business-like initiative of an Islamic-style third sector entrepreneurship has initiated a shift from the conventional to a community-centric business concept.

\section{Conclusions}

The capitalist market economics failed because it is founded on the artificially formulated fundamental assumption that self-interest is the sole motive of human behaviour and actions. This is not tenable. Human nature cannot be conditioned to follow any artificial assumption formulated based on convenience and emotions without reflecting the reality. Thus the market-state entrepreneurship has failed to ensure the wellbeing of people and society. Social enterprise economics (third sector) comprising cooperatives and community-centric not-forprofit social entrepreneurships emerged as a make-up strategy to meet the minimum unmet requirements for social wellbeing. However, a broadly based social enterprise economics with both not-for-profit and for-profit businesses blended with social justice needs to go 
mainstream so that it can have significant impact on the poverty alleviation and bridging the existing economic and social divides through economic growth.

Islamic entrepreneurship is a community-centric mode of business initiative and a natural strategy for solving the problems of economic inequity, the concentration of wealth, and social divides. Therefore, this study finds Islamic entrepreneurship as a highly suitable and effective approach for broadening and mainstreaming the social enterprise economics, primarily in developing countries. Nations and societies that are interested in expanding, developing, and mainstreaming their social enterprise economics may profitably promote this model, which approves seeking of a reasonable profit but puts ethical considerations and community interest above everything else. There is, therefore, a need for credible research and dialogue on community-centric social enterprise economics model specially in terms of its managerial and motivational articulations, and operational sustainability for effective functioning of modern economies.

\section{References}

Balogh, T. (1982).The Irrelevance of Conventional Economics. London: Weidenfeld \& Nicolson. Pp. 109.

Blaug, M. (1980).The Methodology of Economics. Cambridge: Cambridge University Press. pp. 33.

Borzaga, C., Depedri, S., \& Tortia, E. (2009). "The Role of Cooperative and Social

Enterprises: A Multifaceted Approach for an Economic Pluralism." European

Research Institute on Cooperative and Social Enterprises (Euricse) Papers No. 000/09.

Online.http://www.euricse.eu/sites/euricse.eu/files/db_uploads/documents/12695296 38_n360.pdf. Retrieved on 16 June 2014.

Chapra, U. (1996). What Is Islamic Economics? Jeddah: IRTI, Islamic Development Bank, 1996), 24.Online.http://www.irtipms.org/PubText/66.pdf. Retrieved on 16 June 2014.

Chapra, U.M. (1993). Islam and Economic Development. Islamization of Knowledge - 14. The International Institute of Islamic Thought and Islamic Research Institute: Islamabad. pp. 6-7.

Online.http://www.irti.org/irj/go/km/docs/documents/IDBDevelopments/Internet/En glish/IRTI/CM/downloads/Distance Learning_Files/ISLAM\%20AND\%20EOCNO MIC\%20DEVELOPMENT.pdf. Retrieved on 16 June 2014.

Chomsky, Noam. (2001). "The United States is a Leading Terrorist State: An Interview with Noam Chomsky," Monthly Review 53(6).

Online.http://monthlyreview.org/2001/11/01/the-united-states-is-a-leading-terroriststate. Retrieved on 16 June 2014.

Chronology of American State Terrorism (2014).Online. hateusa.narod.ru/terror.htm. Retrieved on 16 June 2014.

Corporate Watch Report (2006). "What's Wrong With Corporate Social Responsibility?", Online. http://www.corporatewatch.org/download.php?id=55. Retrieved on 16 June 2014.

Davies, J. B., Sandström, S., Shorrocks, A., \& Wolff, E. N. (2008).“The world distribution of household wealth". WIDER Discussion Papers No. 2008/03, World Institute for Development Economics (UNU-WIDER).

Online.http://www.wider.unu.edu/publications/working-papers/discussion- 
papers/2008/en_GB/dp2008-03/_files/78918010772127840/default/dp2008-03.pdf. Retrieved on 16 June 2014.

European Research Institute on Cooperative and Social Enterprises (2014). "Philosophy:

Guiding Principles for the Study of Cooperative and Social

Enterprises."Online.http://www.euricse.eu/sites/euricse.eu/files/db_uploads/documen ts/1265989136_n334.pdf. Retrieved on 16 June 2014.

Hillebrand, E. (2009). "Poverty, growth and inequality over the next 50 years."Report FAO. Online.ftp://ftp.fao.org/docrep/fao/012/ak968e/ak968e00.pdf. Retrieved on 16 June 2014.

International Co-operative Alliance.(2014). "Co-operative Identity, Values \& Principles".Online.http://ica.coop/en/whats-co-op/co-operative-identity-valuesprinciples. Retrieved on 16 June 2014.

Islami Bank Foundation (2014). Online. http://www.ibf-bd.org/. Retrieved on 16 June 2014.

Molla, R.I., Moten, A.R., Gusau, S.A, Gwandu, A.A. (1988).Frontiers and Mechanics of Islamic Economics. University of Sokoto: Nigeria. pp. 199-200.

Molla, Rafiqul I., Alam, M.M. \& Murad, M.W. (2011). The Deceptive Game of Today's Capitalist Globalization: Evidence from Malaysia's Experience, European Journal of East Asian Studies 10(2):169-180.

Online.http://www.ingentaconnect.com/content/brill/eeas/2011/00000010/00000002/ art00004. Retrieved on 16 June 2014.

Musa, Z. (2010). "Malaysia can promote Islamic entrepreneurship," The Star Online, April 10.

Online.http://biz.thestar.com.my/news/story.asp?sec=business\&file=/2010/4/10/busi ness/20100410083304. Retrieved on 16 June 2014.

Naqvi, S.N.W. (1981). Ethics and Economics: An Islamic Synthesis. Islamic Foundation: UK. pp. 18.

Samuelson, P.A. (1967). Economics: An Introductory Analysis, 7th ed. New York: McGrawHill Book Company. pp. 44.

Santos, Filipe M. (2009).“A Positive Theory of Social Entrepreneurship”, INSEAD Working Paper No. 2009/23/EFE/INSEAD Social Innovation Centre, (online)

http://www.insead.edu/facultyresearch/centres/social_entrepreneurship/research_reso urces/documents/2009-23.pdf . Retrieved on 16 June 2014.

Shahnaz, D. \& Tan, P.S.M. (2009). "Social Enterprise in Asia: Context and Opportunities." Lee Kuan Yew School of Public Policy Research Paper No.LKYSPP09-018CAG006.Online.http://www.asiaiix.com/wp-content/uploads/2010/03/SocialEnterprise-in-Asia-Context-and-Opportunities3.pdf. Retrieved on 16 June 2014.

Stiglitz, J.E. (2009). Moving Beyond Market Fundamentalism to a More Balanced Economy, Annals of Public and Cooperative Economics 80(3): 345-360.

Online.https://sipa.columbia.edu/sites/default/files/j.1467-8292.2009.00389.x.pdf.

Retrieved on 16 June 2014.

Sutcliffe, B. (2007). Postscript to the article 'World inequality and globalization' (Oxford Review of Economic Policy, Spring 2004), Online.

http://siteresources.worldbank.org/INTDECINEQ/Resources/PSBSutcliffe.pdf.

Retrieved on 16 June 2014.

The Berlin Tagesspiegel Daily. (2002). "Former Top German Minister Rejects Official Story of 9/11 Attacks," Jan 13. Online.www.ratical.org/ratville/CAH/VonBuelow.html. Retrieved on 16 June 2014.

Todaro, M.P. \& Smith, S.C. (2009). Economic Development. New York: Addison-Wesley, pp. 56. 
UNDP. 2008. "Social Enterprise: A New Model for Poverty Reduction and Employment Generation. An Examination of the Concept and Practice in Europe and the Commonwealth of Independent States." (online) http://europeandcis.undp.org/poverty/show/2F171313-F203-1EE9B687694A1F8C9AEC (accessed on 20 January 2011).

United Nations.(2001). "Report of the High-Level Panel on Financing for Development".Online.http://www.un.org/en/ga/search/view_doc.asp?symbol=A/55/1 000. Retrieved on 16 June 2014.

Yunus, M. (2007).“Social Business”. (online) www.muhammadyunus.org/SocialBusiness/social-business. Retrieved on 16 June 2014. 